Article

\title{
Multivariate Analysis of Soil Salinity in a Semi-Humid Irrigated District of China: Concern about a Recent Water Project
}

\author{
Jing Zhang ${ }^{1, *}$, Dong Du ${ }^{1}$, Dongli Ji ${ }^{2}$, Yaonan Bai ${ }^{1}$ and Wanjun Jiang ${ }^{1}$ \\ 1 Tianjin Centre, China Geological Survey, Tianjin 300170, China; yy_cugb@163.com (D.D.); \\ byn2005wh@126.com (Y.B.); JWJ2019CUGB@126.com (W.J.) \\ 2 School of Environmental and Municipal Engineering, Tianjin Urban Construction College, \\ Tianjin 300384, China; donglijihappy@163.com \\ * Correspondence: TJCGSZJ@163.com or zjing2015@mail.cgs.gov.cn
}

Received: 31 May 2020; Accepted: 22 July 2020; Published: 24 July 2020

\begin{abstract}
The Chaobai River (CBR) basin in northern China is experiencing an unprecedented continuous inflow of external water via the South-North Water Diversion Project, which has channeled water from the southern part of the country to the north. Consequently, the steady rise of groundwater table in recent years is threatening soil salinity regulation. The purpose of this study was to describe the status of salinity of the surface soil in the CBR basin and to evaluate the impact of environmental factors including groundwater table on the spatial distribution of soil salinity using multivariate analysis (MVA) technique. In this study, 10 chemical variables of soil samples collected in 204 sites along CBR were analyzed, considering their interaction with three environmental factors: the density of irrigation canals, groundwater depth and topography. Statistical analysis mainly consisted of principal component analysis (PCA), redundancy analysis (RDA) and clustering analysis (CA). The results allow defining the surface soil in the CBR basin as a slightly saline and moderately alkaline media. The first two axes of multivariate model approximately explains $51 \%$ of the observed variability and allows distinguishing two main domains: the saline and the alkaline. The variability of the saline domain, defined by major cations and anions, is obviously controlled by macro environmental factors, of which the density of irrigation canals and groundwater depth contributes $71 \%$ and $28 \%$, respectively, while that of the alkaline domain, related to $\mathrm{pH}$ and bicarbonate, mainly manifests as singular behaviors of soil groups like rice cultivation or sewage irrigation. The results suggests that more attention should be paid to the ongoing water table rise to help inform future land management decisions and to prevent a double threat of both groundwater and surface water on soil salinization. Meanwhile, this study shows the enormous potential of MVA technique, specifically the complementary duo of RDA and CA, for integrating both global and local information of soil salinity and environmental factors.
\end{abstract}

Keywords: soil salinity; Chaobai River; groundwater; principal component; redundancy analysis; spatial clustering

\section{Introduction}

The mother river of the Chinese national capital Beijing and Tianjin municipality-the Chaobai River (CBR), has given birth to generations of civilization and now is the important grain and vegetable base of the two megacities [1,2]. Nevertheless, the CBR basin was once known as a saline-alkaline, waterlogged, flood-prone and low-yielding region due to high groundwater table in the 1950s, and at that time, soil salinity constituted a major factor limiting crop production [3,4] because it affects plant growth and survival [5]. The period from 1950s onward for a few decades witnessed successful 
prevention of the salinization, the area of saline land reducing from 120 to 5 hectares, for which the grain yields increased greatly [6]. The main reason for the reversal of salinization during this period was believed to be related to the increasing demand for water by the society. The severe overextraction of groundwater resulted in an about $30 \mathrm{~m}$ drop of groundwater table from 1959 to 2009 [7], which provided favorable conditions for soil desalting.

The government has tried to curb the rapid decline of the groundwater table for years because it caused serious problem of ecological damage [8] and land subsidence [9]. The famous South-North Water Diversion Project (middle route), starting construction in 2003 with completion and launching in 2014, channels water from Danjiangkou Reservoir in Hubei province, a water-rich place more than $800 \mathrm{~km}$ from Beijing, to north China at a rate of about one billion cubic meters every year [10] (Figure 1). In 2016, the groundwater table in the plain area of Beijing stopped dropping to rebound. In 2018, the groundwater table in the CBR basin generally rose by 6-8 $\mathrm{m}$ compared to the previous year, including $12 \mathrm{~m}$ in the recharge center. It is predicted that there will be a continuous $9-11 \mathrm{~m}$ rise of groundwater table till $2022[11,12]$. The regional rise of groundwater table may pose a threat to soil salinity regulation, but to what extent is a matter of unknown at present.

Multivariate analysis (MVA) is a very useful technique in soil research because it can simplify multivariate datasets without a substantial loss of information [13]. It allows for handling highly collinear variables-as is often the case in soil studies-and accounting for the effects of environmental factors. There are three main classes of MVA which are used in environmental analyses: (i) unconstrained ordination or indirect gradient analysis, for example, principal components analysis (PCA), which ranks observations along variation axes that represent gradients derived from intrinsic factors; (ii) constrained ordination or direct gradient analysis, for example, the redundancy analysis (RDA), in which a supplemental set of explanatory variables (environmental factors) is incorporated to ordination, and the effects of this set on the original variables are evaluated by regression analysis and (iii) cluster analysis (CA), in which the observations are assigned into clusters on the basis of their similarity [14]. The three analytical methods have been always used in the research of ionic composition of soil [15] and the effects of the soil chemical properties on vegetation [16]. A combined analysis of all the three tools had been not performed in soil research until 2019 in the irrigated district of Flumen in Spain [17] and has proven to be quite effective in the study of soil salinity. However, the viability of this combined analysis method in a large basin has not been verified.

In this context, the objective of this research is to characterize both the amount and distribution of soil salinity in the CBR basin. Furthermore, the relationship between these solutes and certain environmental factors including the density of irrigation canals, groundwater depth and topography is explored through the application of MVA in order to give some references for the prevention and control of soil salinity in the future.

\section{Materials and Methods}

\subsection{Study Area}

The Chaobai River basin is located in the north of North China Plain, between $39^{\circ} 19^{\prime}$ and $40^{\circ} 20^{\prime} \mathrm{N}$ and $116^{\circ} 25^{\prime}$ and $117^{\circ} 30.5^{\prime} \mathrm{E}$ (mountainous areas are not included). The whole basin extends across the prefectures of Beijing city, Hebei province and Tianjin city, and is bounded by the rivers Wenyu and $\mathrm{Ju}$ with an area of $3870 \mathrm{~km}^{2}$. The regional landscape is mostly flat, except for a slight rise from the southeast to the northwest, with elevations in the 1-58 m range. The NW-SE directions also define the flux of groundwater (Figure 1). This region is characterized by a temperate continental monsoon climate, with warm humid summers and cold arid winters, an average annual temperature of $11.6{ }^{\circ} \mathrm{C}$ and average annual rainfall of $606.8 \mathrm{~mm}$ [18]. The average annual pan evaporation (measured by a $20 \mathrm{~cm}$ pan) is around $1700 \mathrm{~mm}$ [19]. 


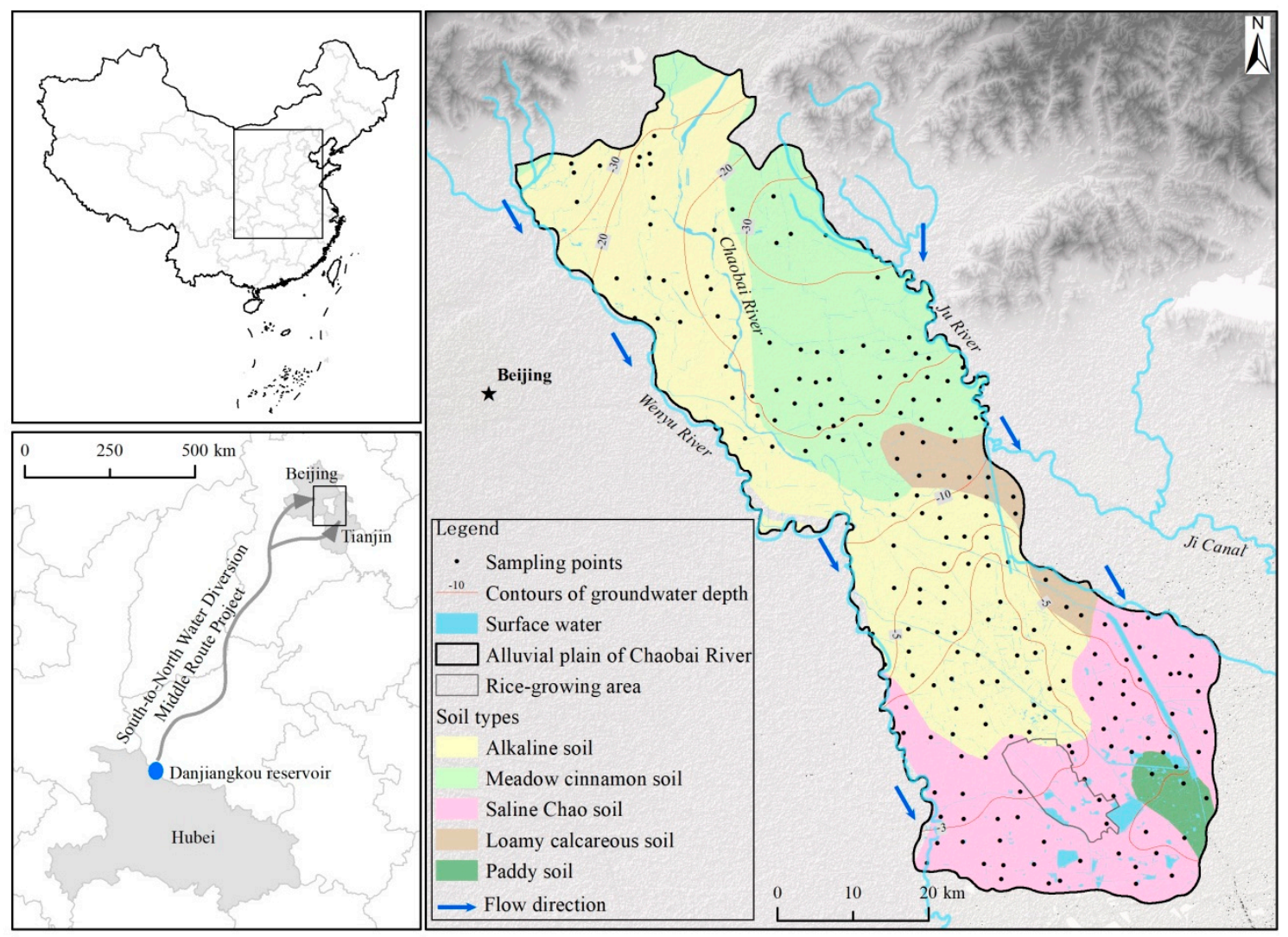

Figure 1. Location of the Chaobai River Basin (CBR) and the sampling points in relation to the South-North Water Diversion Project (middle route). Contours of groundwater depth and surface water such as rivers and canals are also shown.

The plowing layer mainly consists of silty clay, clay silt and silt, and was formed in the Holocene. The primary type of surface soil is Chao soil, which can be divided into four subclasses: alkaline soil; meadow cinnamon soil; saline Chao soil and loamy calcareous soil [20]. In these conditions, irrigation practices began at least 2000 years ago at the riverbanks and were extended to include most of the land in the 1980s [21]. At the same time in the 1980s, a history of sewage irrigation began and continued until today. Nowadays, Tianjin has the largest area of sewage irrigation in China, followed by Beijing [22]. The ionic concentrations of irrigation water are relatively high and are increasing year-by-year [23], so a significant amount of irrigated lands are salt-affected. The main crops are wheat, corn and soybeans, where rice is only grown in the southeast part of the area [24].

\subsection{Sampling and Laboratory Analyses}

Sampling was carried out in July and August 2019, under dry soil conditions. A total of 204 soil samples were taken in the topsoil at $20-30 \mathrm{~cm}$ deep. The sampling sites were uniformly distributed and had good coverage of the study area, except some individual areas conditioned by their limited accessibility. An Eijkelkamp auger was adopted to obtain the soil samples, then they were air dried and sieved through a 2-mm mesh before laboratory analyses.

The suspensions were made by 1:5 soil-water extracts and all samples were analyzed for cations such as potassium $\left(\mathrm{K}^{+}\right)$, sodium $\left(\mathrm{Na}^{+}\right)$, calcium $\left(\mathrm{Ca}^{2+}\right)$ and magnesium $\left(\mathrm{Mg}^{2+}\right)$ and for anions such as sulfate $\left(\mathrm{SO}_{4}{ }^{2-}\right)$, chloride $\left(\mathrm{Cl}^{-}\right)$, nitrate $\left(\mathrm{NO}_{3}{ }^{-}\right)$, carbonate $\left(\mathrm{CO}_{3}{ }^{2-}\right)$ and bicarbonate $\left(\mathrm{HCO}_{3}{ }^{-}\right)$. Soil $\mathrm{pH}$ were measured in 1:2.5 suspension in water at the same time. Standard methods were used for laboratory testing: $\mathrm{Na}^{+}$and $\mathrm{K}^{+}$(atomic emission spectrophotometry), $\mathrm{Ca}^{2+}, \mathrm{Mg}^{2+}, \mathrm{SO}_{4}{ }^{2-}, \mathrm{Cl}^{-}$, $\mathrm{NO}_{3}{ }^{-}, \mathrm{CO}_{3}{ }^{2-}$ and $\mathrm{HCO}_{3}{ }^{-}$(absorption spectrophotometry with a continuum-flux autoanalyzer), $\mathrm{pH}$ (potentiometric determination). 
The considered three environmental factors include topography, groundwater depth and the density of irrigation canals because they are intimately related to soil chemical properties. The topography and groundwater depth are, respectively in quantitative terms of elevation (meters above sea level) and the distance between the surface and groundwater table (negative value). Both of them were measured in the field survey, which conducted simultaneously with soil sampling. The depth of the wells selected for measurement is less than $80 \mathrm{~m}$, so as to ensure that the data can represent the state of shallow groundwater. The groundwater depth at the sampling sites can be obtained by kriging interpolation [25]. The density of irrigation canals is defined as the area proportion of canals in the circle of radius one kilometer around sampling sites. The information of these canals were interpreted from the Worldview-4 remote sensing data (a resolution of $0.31 \mathrm{~m}$ ) [26].

\subsection{Statistical Analyses}

A descriptive statistical analysis was conducted first, in which mean, median, maximum, minimum, standard deviation, coefficients of variation, skewness and kurtosis were calculated. Then Pearson correlation analysis was performed to assess the relationships and associations among variables.

A multivariate gradient analysis, combining ordination and multiple regression techniques, was carried out to integrate the information of spatial variability and relationships between soil salinity and environmental factors. The ordination is aimed at finding canonical axes that explain the maximum variability in the chemical properties of the samples. Unconstrained ordination (i.e., indirect gradient analysis) seeks the variables that could best explain the saline ions composition and takes them as ordination axes. On the other hand, in constrained ordination (i.e., direct gradient analysis), variability is confined to be only explained in terms of the environmental factors. The two approaches complement each other. The main gradient of variability is obtained via the former indirect method, while with the latter direct one only the variability associated with the environmental factors is involved.

According to the analysis of the gradient length [27], which antecedently conducted on the response dataset, a linear analysis model was selected and thus determining the two methods of PCA and RDA, respectively used for indirect gradient analysis and direct gradient analysis. Before analysis, the data were standardized by standard deviation for PCA and by error variance for RDA. Monte Carlo permutation tests were adopted to evaluate the signification of ordination axes.

CA was used in this study to explain the principal component axes that can't be interpreted effectively in RDA. To identify the type of spatial correlation, the Local Moran's I [28] is used as an indicator of local spatial association to provide a measure of association for each unit. The local measure of Moran's I is defined as:

$$
I_{i}=\frac{n}{(n-1) S^{2}}\left(x_{i}-\bar{x}\right) \sum_{j} w_{i j}\left(x_{j}-\bar{x}\right)
$$

where $x_{i}$ is the normalized score of the principal component at a particular sample, $x_{j}$ is the normalized score of the principal component at another neighboring sample, $\bar{x}$ is the average normalized score, $w_{i j}$ is a weight that denotes the proximity between samples $i$ and $j, \mathrm{n}$ is the number of samples, and $S^{2}$ is the variance of the normalized scores of the principal components. The Moran scatter plot helps identify areas where the point values are similar or dissimilar and categorizes them into the following clusters: low values surrounded by low values (LL), high values surrounded by high values (HH) and outliers, either a high value surrounded by low values (HL) or a low value surrounded by high values $(\mathrm{LH})$ and the others without significant abnormality $(\mathrm{O})$.

Data standardization was completed in SPSS 24 (IBM, Chicago, IL, USA). The PCA and RDA were conducted with Canoco 5.0 (Microcomputer Power, New York, NY, USA) [29]. The Local Moran's I was performed with Arcgis 10.1 (ESRI, Redlands, CA, USA) [30]. 


\section{Results and Discussion}

\subsection{General Features of the Soil Ionic Composition}

Descriptive statistics for soil ionic composition are shown in Table 1 . The average concentration soil salt is $1.1 \mathrm{~g} / \mathrm{kg}$, meeting the standard of slight salinization [31]. The average concentrations of major anions and cations decrease as follows: bicarbonate $>$ sulfate $>$ chloride $>$ nitrate and sodium $>$ calcium $>$ magnesium $>$ potassium. The first three cations are the most abundant in salt affected soils [32,33]. The concentration of bicarbonate, which has the highest level among the anions, is approximately in accordance with the records in the Luan River delta $60 \mathrm{~km}$ east of the study area [34] and the Manas River watershed in northwestern China [35] and is larger than many other regions in the world [15,17,36]. The accumulation of bicarbonate leads to a trend of soil alkalization [37], so the measured soil $\mathrm{pH}$ ranges mainly between 7.5 and 8.5 , which is a typical range of soil $\mathrm{pH}$ in the North China plain [38], up to 9.85. Therefore, according to the threshold values of soil chemical variables set by Chinese soil society [31], the soil can be described as slightly saline and moderately alkaline.

Table 1. Descriptive statistics of chemical composition of soil samples $(n=204)$ from the Chaobai River (CBR) basin. Those of environmental factors are also shown.

\begin{tabular}{|c|c|c|c|c|c|c|c|c|c|}
\hline $\begin{array}{c}\text { Soil Variables/ } \\
\text { Environmental } \\
\text { Factors }\end{array}$ & Units & $\operatorname{Min}^{\mathbf{a}}$ & $\operatorname{Max}^{b}$ & Mean & Median & $\mathrm{SD}^{\mathrm{c}}$ & $\mathrm{CV}^{\mathrm{d}}$ & Skewness & Kurtosis \\
\hline $\mathrm{CO}_{3}{ }^{2-}$ & $\mathrm{mg} / \mathrm{kg}$ & $<1$ & 120.04 & 4.94 & $<1$ & 14.63 & 2.96 & 5.05 & 32.32 \\
\hline $\mathrm{HCO}_{3}{ }^{-}$ & $\mathrm{mg} / \mathrm{kg}$ & 14.00 & 1039.90 & 304.72 & 275.00 & 155.32 & 0.51 & 2.08 & 5.98 \\
\hline $\mathrm{SO}_{4}^{2-}$ & $\mathrm{mg} / \mathrm{kg}$ & 12.00 & 4383.00 & 260.00 & 123.10 & 449.66 & 1.73 & 5.45 & 40.04 \\
\hline $\mathrm{Cl}^{-}$ & $\mathrm{mg} / \mathrm{kg}$ & 7.00 & 1040.00 & 131.50 & 57.60 & 163.53 & 1.24 & 2.25 & 6.18 \\
\hline $\mathrm{NO}_{3}{ }^{-}$ & $\mathrm{mg} / \mathrm{kg}$ & $<0.5$ & 2504.60 & 13.44 & $<0.5$ & 176.06 & 13.10 & 14.10 & 200.34 \\
\hline $\mathrm{K}^{+}$ & $\mathrm{mg} / \mathrm{kg}$ & 1.00 & 847.00 & 18.77 & 8.05 & 64.72 & 3.45 & 11.10 & 136.35 \\
\hline $\mathrm{Na}^{+}$ & $\mathrm{mg} / \mathrm{kg}$ & 4.00 & 1130.40 & 184.37 & 105.30 & 202.05 & 1.10 & 2.02 & 4.68 \\
\hline $\mathrm{Ca}^{2+}$ & $\mathrm{mg} / \mathrm{kg}$ & 13.00 & 1009.00 & 107.11 & 74.00 & 109.98 & 1.03 & 3.89 & 23.78 \\
\hline $\mathrm{Mg}^{2+}$ & $\mathrm{mg} / \mathrm{kg}$ & $<1$ & 396.00 & 31.42 & 21.10 & 41.03 & 1.31 & 5.17 & 36.01 \\
\hline $\mathrm{pH}$ & & 5.95 & 9.85 & 8.04 & 8.05 & 0.47 & 0.06 & -0.74 & 3.92 \\
\hline Elevation & $\mathrm{m}$ & 0.20 & 47.00 & 9.54 & 6.00 & 10.07 & 1.06 & 1.84 & 2.67 \\
\hline GWD $^{\mathrm{e}}$ & $\mathrm{m}$ & -40.98 & -1.80 & -10.55 & -5.97 & 8.88 & -0.84 & -1.12 & 0.52 \\
\hline Canal density & & 0.00 & 0.48 & 0.07 & 0.04 & 0.07 & 1.00 & 2.39 & 8.02 \\
\hline
\end{tabular}

Generally high coefficients of variation $(\mathrm{CV})$ were observed in the data with the exception of $\mathrm{pH}$. Agreeing with the results from previous studies, $\mathrm{CV}$ is particularly high in the case of $\mathrm{NO}_{3}{ }^{-}$and $\mathrm{K}^{+}$ due to the uneven application of chemical fertilizer $[39,40]$, although the average concentrations of them are lower than in the adjacent area [34]. From a global perspective, the high variability of $\mathrm{NO}_{3}{ }^{-}$ seems to be widespread, which not only existed in irrigation districts, but also in natural wetland with little anthropogenic activities [15].

All anions and cations show positive skewness because of the presence of large values. This suggests an either natural or anthropogenic enrichment of main ions in the surface soil [41]. The observed asymmetry and the high kurtosis coefficients indicate the non-normal distribution of the data, which is verified by the Kolmogorov-Smirnov test. Only $\mathrm{pH}$ appears to be approximately normal distribution. The non-normality of the distribution of soil chemical properties is more of a rule than an exception due to the heterogeneity of the soil system and its complex interactions with the environmental factors, as has been demonstrated by other researchers [42,43]. Logarithmic transformation can partially overcome the general absence of symmetry in main ions [44].

The results of bivariate correlation analysis are shown in Table 2. Strong correlations generally exist among major anions and cations. The highest correlation is found between sodium and chloride $(r=0.86)$, comparable to that found in other works $[32,45,46]$. Potassium is the cation least correlated with the rest of major anions and cations $(r<0.2)$, indicating that in highly saline points dominated by 
sodium and calcium, the concentration of potassium is low because the two of sodium and calcium have high correlations with the major anions. $\mathrm{pH}$ was slightly negatively correlated with the $\mathrm{Ca}^{2+}$, but strongly and positively correlated with bicarbonate and carbonate, following the law of chemical reactions among the three ions when $\mathrm{pH}$ ranges between 8 and 10 [47].

Table 2. Bivariate Pearson correlation coefficients $(r)$ for soil chemical variables.

\begin{tabular}{|c|c|c|c|c|c|c|c|c|c|c|}
\hline Soil Variables & $\mathrm{CO}_{3}{ }^{2-}$ & $\mathrm{HCO}_{3}^{-}$ & $\mathrm{SO}_{4}{ }^{2-}$ & $\mathrm{Cl}^{-}$ & $\mathrm{NO}_{3}^{-}$ & $\mathbf{K}^{+}$ & $\mathrm{Na}^{+}$ & $\mathrm{Ca}^{2+}$ & $\mathrm{Mg}^{2+}$ & $\mathrm{pH}$ \\
\hline $\mathrm{CO}_{3}^{2-}$ & 1.00 & & & & & & & & & \\
\hline $\mathrm{HCO}_{3}{ }^{-}$ & -0.04 & 1.00 & & & & & & & & \\
\hline $\mathrm{SO}_{4}^{2-}$ & 0.01 & -0.01 & 1.00 & & & & & & & \\
\hline $\mathrm{Cl}^{-}$ & $0.17^{*}$ & 0.01 & $0.53^{* *}$ & 1.00 & & & & & & \\
\hline $\mathrm{NO}_{3}{ }^{-}$ & 0.03 & -0.06 & 0.04 & 0.12 & 1.00 & & & & & \\
\hline $\mathrm{K}^{+}$ & 0.03 & 0.00 & 0.14 * & 0.15 * & 0.04 & 1.00 & & & & \\
\hline $\mathrm{Na}^{+}$ & $0.20^{* *}$ & 0.07 & $0.62^{* *}$ & $0.86^{* *}$ & 0.12 & $\begin{array}{c}0.19 \\
* *\end{array}$ & 1.00 & & & \\
\hline $\mathrm{Ca}^{2+}$ & -0.04 & $0.24^{* *}$ & $0.73^{* *}$ & $0.27^{* *}$ & $0.24^{* *}$ & 0.02 & $\begin{array}{c}0.21 \\
* *\end{array}$ & 1.00 & & \\
\hline $\mathrm{Mg}^{2+}$ & -0.11 & 0.04 & $0.84^{* *}$ & $0.37^{* *}$ & $0.34^{* *}$ & 0.10 & $\underset{* *}{0.38}$ & $\underset{* *}{0.77}$ & 1.00 & \\
\hline $\mathrm{pH}$ & $0.50 * *$ & $0.36^{* *}$ & $-0.17 *$ & -0.11 & $-0.17 *$ & 0.01 & -0.10 & $\begin{array}{c}-0.03 \\
*\end{array}$ & $\begin{array}{c}-0.22 \\
* *\end{array}$ & 1.00 \\
\hline
\end{tabular}

* Indicate significant correlation at the 0.05 probability level; ${ }^{* *}$ indicate significant correlation at the 0.01 probability level.

\subsection{Main Gradients in the Soil Ionic Composition}

The contribution of PCA can be measured by the eigenvalues $\left(\lambda_{\mathrm{i}}\right)$ of principal component axes. The first four axes explain $75 \%\left(\lambda_{1}=0.34, \lambda_{2}=0.17, \lambda_{3}=0.14, \lambda_{4}=0.10\right)$ of the total variance. Table 3 shows the loadings of soil variables on the four principal components axes. Considering small contributions of axis 3 and axis 4 to the total variance, as well as the absence of actual significance of axis 3 , the following analysis would focus only on the first two axes.

Table 3. Load matrix of first four principal components of soil variables.

\begin{tabular}{rcccccccccc}
\hline $\mathbf{P C}^{\mathbf{a}}$ & $\mathbf{C O}_{3}{ }^{2-}$ & $\mathbf{H C O}_{3}{ }^{-}$ & $\mathbf{S O}_{4}{ }^{2-}$ & $\mathbf{C l}^{-}$ & $\mathbf{N O}_{3}{ }^{-}$ & $\mathbf{K}^{+}$ & $\mathbf{N a}^{+}$ & $\mathbf{C a}^{2+}$ & $\mathbf{M g}^{2+}$ & $\mathbf{p H}$ \\
\hline 1 & 0.01 & 0.04 & 0.50 & 0.39 & 0.16 & 0.11 & 0.40 & 0.40 & 0.47 & -0.12 \\
2 & 0.59 & 0.30 & -0.02 & 0.22 & -0.17 & 0.11 & 0.25 & -0.06 & -0.17 & 0.62 \\
3 & -0.13 & 0.54 & 0.07 & -0.37 & 0.02 & -0.22 & -0.37 & 0.47 & 0.24 & 0.31 \\
4 & 0.45 & -0.33 & -0.14 & -0.12 & 0.76 & -0.17 & -0.15 & 0.08 & 0.11 & 0.10 \\
\hline \multicolumn{8}{c}{ a Principal component. }
\end{tabular}

Figure 2 shows the ordination results of the first two axes. Correlations can be evaluated by perpendicularly projecting the arrows of the other variables onto those of the targeted variables [48]. In this case, two different chemical environments can be identified in the soils of the CBR basin: the saline domain and the alkaline domain. The former is defined by major cations and anions, which assigned high positive value on axis I. The latter is related to $\mathrm{pH}$, bicarbonate and carbonate, which take main positive loadings of axis II. The gathering of the arrows within the two domains agrees with the already commented correlation between the chemical variables. Moreover, the separation of potassium from the other ions is also observed, further confirming their low correlation. Therefore, the biplot synthesizes the results of the correlation analysis. 


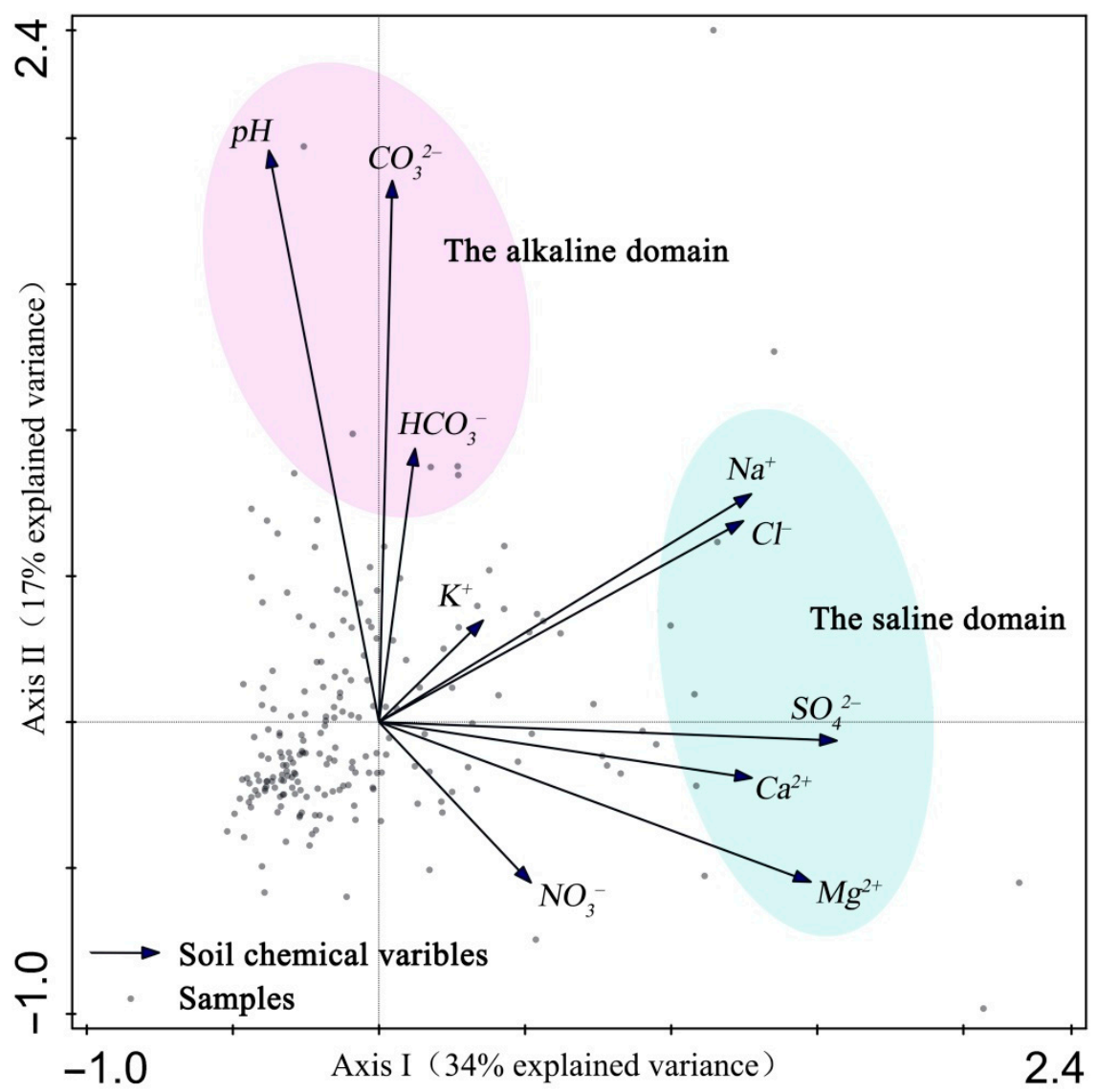

Figure 2. Ordination diagrams from the correlation-based indirect gradient analysis (PCA). Variability explained by the first two axes (correlation biplot) of the distribution of 10 chemical variables in 204 soil samples is represented.

The unconstrained variability explained by the first two principal component axes (51\%) can be comparable with the $54 \%$ observed by Vestin et al. (2006), considering that their work was carried out in a homogenous forest growing in cold climates, but a bit poorer than the $59 \%$ in a wetland [15], the $64 \%$ in an irrigated lowland [32] and the $69 \%$ in an irrigated hilly region [17]. It is not difficult to find that good homogeneity, little artificial interference and closeness of the soil system can be beneficial to the gathering of variability of soil chemical properties toward the principal component axes [15]. The CBR basin is more than 15 times the study area of any other researches mentioned above and has active exchange of surface water and groundwater with not only the adjacent basin, but also remote ecological system (Figure 1). Moreover, the two megacities of Beijing and Tianjin bring strong anthropogenic activities and intensively changed the pedologic characteristic in topsoil. All of these led to the relative low percentage of explained variability. Even so, the significances that the first two axes in this and previous studies stand for were similar. The first axis were highly correlated with soil salinity (electrical conductivity and main ions), while their second axis were linked to alkalinity and nutrients ( $\mathrm{pH}$, bicarbonate and dissolved organic carbon).

In general, the samples are distributed evenly around the origin of the coordinate, except for some individual points showing high scores on both two axes. The distance between the samples is a measure of the degree of their dissimilarity in chemical composition, and the farther the distance, the greater the difference. Viewed this way, the observed commonly proximity between samples can be attributed to the fact that they have been taken in surface soil in the same basin. 


\subsection{Main Factors Affecting the Soil Ionic Composition}

\subsubsection{Saline Domain}

In the RDA, ordination was constrained to be in terms of the three environmental factors: the density of irrigation canals, groundwater depth and topography (the information of them is shown in Figure 1 and Table 1). The first two ordination axes in the RDA account for $21 \%$ of the variance in the data, dominated by the first axis $\left(\lambda_{1}=0.20, \lambda_{2}=0.01\right.$, Figure 3$)$. It means that the environmental factors account for $59 \%$ and $6 \%$ of the unconstrained variability explained by PCA respective in axes I and II, the significance of which is proved by the Monte Carlo tests based on 999 permutations. According to these results, it can be inferred that the saline domain in PCA could be well explained by the environmental factors, whereas the alkaline domain can't.

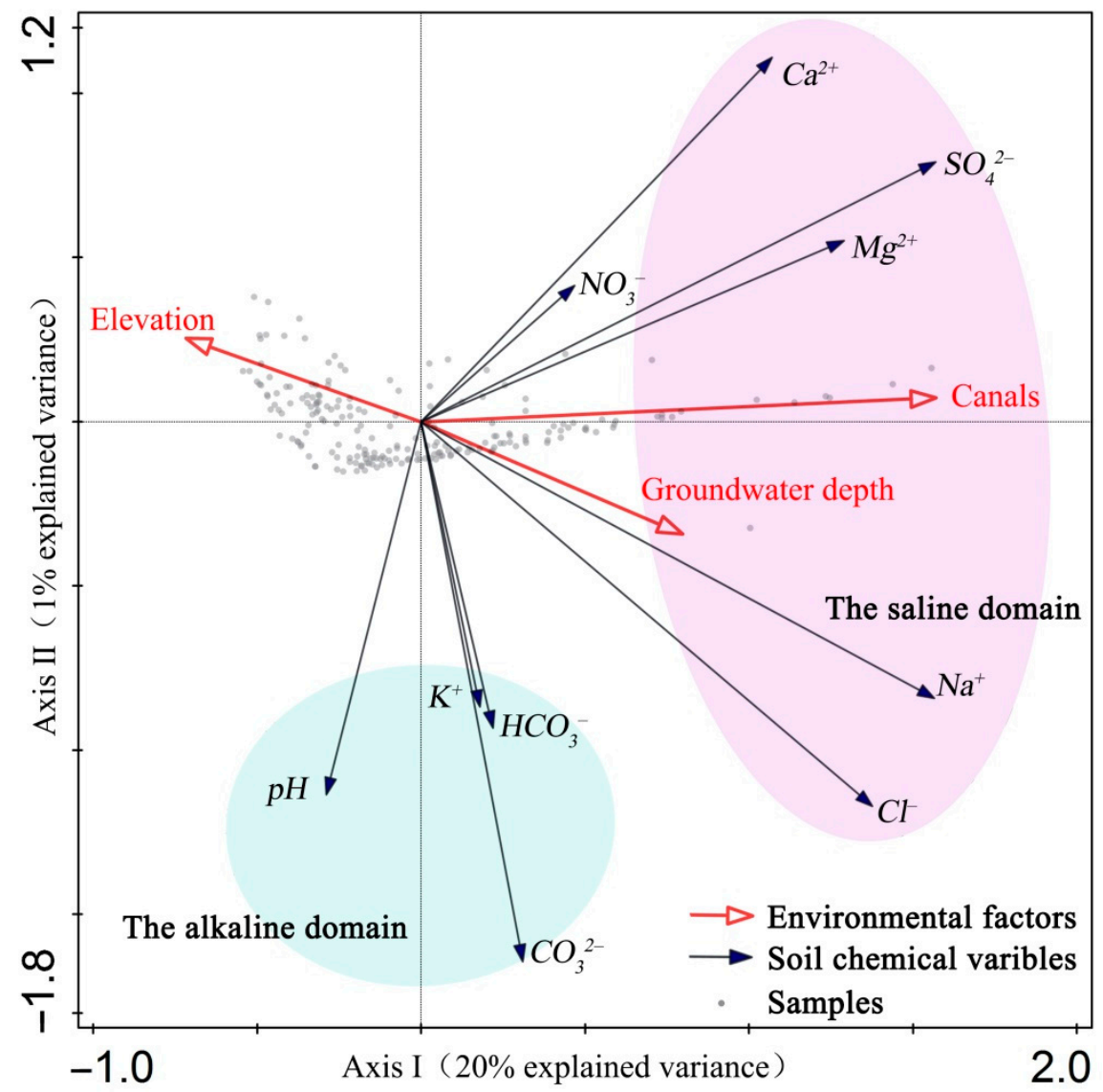

Figure 3. Ordination diagrams from the correlation-based direct gradient analysis (RDA). Variability explained by the first two axes (correlation triplot) of the relationship between soil chemical variables and the environmental factors for the 204 sampling points.

Saline ions tend to accumulate in the areas where irrigation canals densely distributed (Figure 3). The contribution of canals to axis I is $71 \%(p=0.002)$, the most of the three factors. Given the history of sewage irrigation derived from 1980s in the CBR basin [22], a close relationship between the chemical characters of irrigation water and topsoil can be inferred. A long-term record of chemical characteristic of irrigation water in a canal in the middle reach of CBR shows sustained high value of bicarbonate content [49], which in accordance with soil tests. Continuous increase of chloride, sulfate and sodium between 1980-2007 was also observed. Scholars attributed this increase to domestic and industrial sewage water, during which the population exploded, and industry rapidly developed. It is worth noting that sulfate saw the largest increase, approximate $50 \%$, among all of the ions, which may explains the accumulation of sulfate in the soil. The reason for its large rise is probably related 
to the absence of regulation for limiting sulfate in national standard (Chinese quality of farmland irrigation water, GB20922-2007). In fact, even though the emission standard of TDS was specified (less than one gram per liter), substandard salt was often detected in the processed sewage water [22]. Considering the significance for water conservation and regulation, sewage irrigation will no doubt continue. In this condition, it is essential to improve the supervision of wastewater treatment plant. Some positive changes were predicted that the water with low salinity in Danjiangkou Reservoir would dilute the surface water in CBR basin after South-North Water Diversion Project launched [50]. However, the dilution has not been observed so far.

Topography has the opposite effect of groundwater depth on soil salinity, so their arrows are drawn in a straight line in opposite directions (Figure 3). The groundwater depth contributes $28 \%$ to axis I $(p=0.002)$ and the topography contributes $1 \%(p=0.01)$. The little percentage of the topography can be attributed to its strong correlation with the groundwater table [51]. These results have much in common with previous studies carried out in other different landforms [52,53]. These researches demonstrated that, in most cases, the distribution of soil salinity under natural conditions is in connection with the location of the soil in the topographic unit, ranging from the high and sloping fields having deep groundwater table without salt-affected soils to the moderately to strongly saline soils in the bottoms having shallow groundwater table [17].

According to recent monitoring, TDS of the shallow groundwater in the study area ranges from 0.5 to $1 \mathrm{~g} / \mathrm{L}$ [2], which seems safe compared to surface water. However, there are threat of groundwater to soil salinization, more depending on evaporation intensity. Once the groundwater table reach salt-returning line, such groundwater is capable to provide much salt to topsoil just like it did in the 1950s [50]. In the past few decades, the influence of groundwater table on soil salinity in CBR basin has been of little concern, because most areas have a safe groundwater level which benefited from long-term overexploitation of groundwater. However, the present situation seems somewhat different. According to previous studies, the critical depth of groundwater in salinization of soil in western China is believed to range between 2.5-2.7 $\mathrm{m}[54,55]$, while about $3.5 \mathrm{~m} \mathrm{[56]} \mathrm{in} \mathrm{eastern} \mathrm{China}$ where the CBR basin belongs to. In our investigation, of groundwater depth, $25 \%$ of the data are less than $3.5 \mathrm{~m}$ and the ones less than $6 \mathrm{~m}$ account for about half. Moreover, the results would have been more severe if the survey were conducted in winter, the peak season of groundwater table in a year [57]. What seems certain is that the groundwater level will keep rising in the coming years due to the continuous inflow of water by South-North Water Diversion Project, and there will be more soils at the risk of salinization. Therefore, managers must find the right balance between their stand of groundwater and salinization of soil.

\subsubsection{Alkaline Domain}

As the RDA had shown, the three environmental factors, characterized by macroscopy, were incapable to explain the variation of the soil alkaline domain. Therefore, CA was conducted to help distinguish groups of soils having similar behaviors. On the basis of the scores of axis II in PCA, CA divided all the samples into three categories including 4 clusters: LL (Cluster 1 and Cluster 2 with relatively weak alkalinity), $\mathrm{HH}$ (Cluster 3 with relatively strong alkalinity) and $\mathrm{O}$ (the others without significant abnormality) (Figure 4a, Figure 5). 

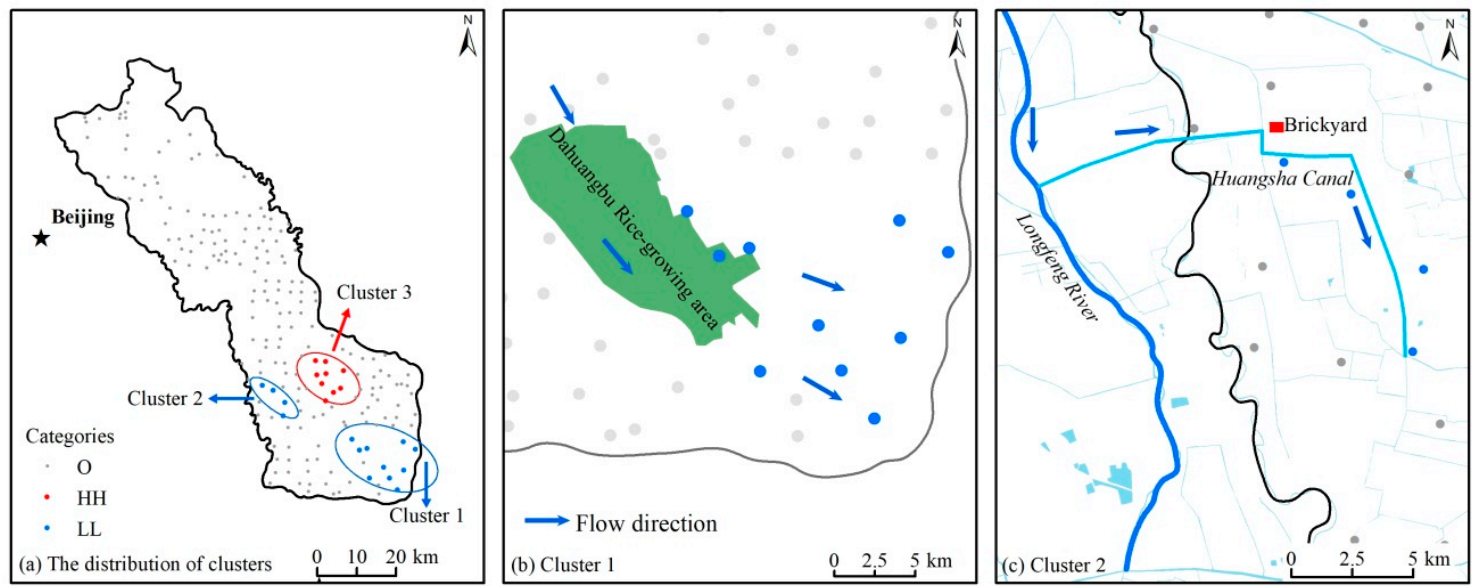

Figure 4. (a) Distribution of clusters from the cluster analysis (CA). Surrounding environment of (b) Cluster 1 and (c) Cluster 2 are also shown.
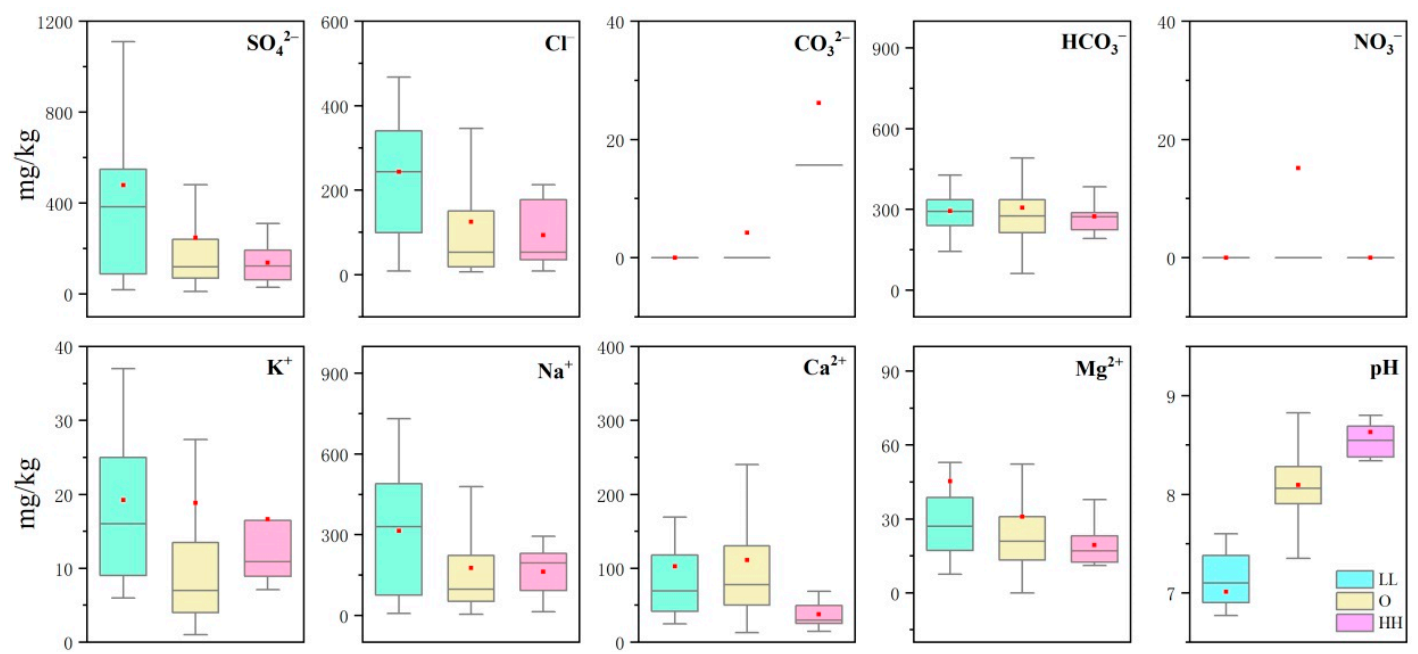

Figure 5. Box-plots showing the differences in three categories ( $\mathrm{LL}, \mathrm{HH}$ and $\mathrm{O}$ ) of $\mathrm{SO}_{4}{ }^{2-}, \mathrm{Cl}^{-}, \mathrm{CO}_{3}{ }^{2-}$, $\mathrm{HCO}_{3}{ }^{-}, \mathrm{NO}_{3}{ }^{-}, \mathrm{K}^{+}, \mathrm{Na}^{+}, \mathrm{Ca}^{2+}, \mathrm{Mg}^{2+}$ and $\mathrm{pH}$ from the sampled soils $(n=204)$.

Cluster 1 is distributed in the lowest part of the entire basin (Figure $4 a, b$ ). The average $\mathrm{pH}$ in this group was well below its overall level (Figure 5). It is worth mentioning that the upper reaches of this cluster are adjacent to a perennial rice-growing area. Since the $\mathrm{pH}$ value suitable for the growth of rice is less than 7 [58], particularly $4.5-5.5$ for rice seedling [59], the application of acidulent is essential to prevent some diseases against the background of alkalinity. Obviously, the acidulent reduced soil $\mathrm{pH}$ and this influence expanded downstream with the acid flowing in canals and groundwater.

Rice growing and alkalinity of soil affect each other and that varies by location. In China, the dominant areas of this crop are mainly distributed to the south of the Yangtze River and in the Northeast Plain, where the soils are naturally acidic and suitable for rice cultivation [60]. By contrast, in the regions with moderate alkaline soil like north china plain, manual intervention on soil $\mathrm{pH}$ is necessary to ensure good health of seedlings [59]. Some scholars have already paid attention to the influence of application of acidulants on soil $\mathrm{pH}$ but find some limits during the acidization [58] due to the presence of $\mathrm{pH}$ buffer system existed in paddy soils under the persistent flooding condition. Consequently, after long-term planting of rice, the soil $\mathrm{pH}$ generally tends to be neutral [58], which is consistent with our results (the average $\mathrm{pH}$ value of Cluster 1 is 7.04, Figure 5). In some cases, rice also grown in highly saline and alkaline soils, for example, Flumen in Spain [17] where rice is the only profitable crop. Nonetheless, rice cultivation here seems powerless to reduce $\mathrm{pH}$ because of 
inherent strong alkalinity. Given the above, although it matters, rice-growing cannot simply be an indicator of acidity.

Cluster 2 is characterized by linear distribution along the Huangsha canal near the western border of lower reaches (Figure 4c). Therefore, the abnormality of this cluster, high concentrations of major ions such as sodium, potassium, chloride and sulfate (Figure 5), may have something to do with this canal. On one hand, Huangsha canal is a branch of the Longfeng River (Figure 4c), one of the three most rivers loaded by sewage in the basin [22]. The industrial and domestic wastewater in this river showed typical features of high salinity and acidity, which is highly consistent with the chemical statistics of Cluster 2. On the other hand, a brick factory in operation was found to be located upstream of Cluster 2 through the interpretation of remote sensing, confirmed by field survey. In order to obtain materials for brick making, several gigantic pits were excavated to carry an exposure of groundwater so that industrial pollutants can easily enter into groundwater and spread downstream. However, further investigation is suggested to verify the above views.

Compared with the first two groups of soil, Cluster 3 is the one with stronger alkalinity, distributed in the lower reaches. It is difficult to determine whether its identification is due to human activities, because a slightly natural enrichment of alkalinity originally tends to appear in the bottom of the basin with the accumulation of alkalis like sodium (Figure 3). In this condition, the spatial relationships that Cluster 3 is surrounded by the other two clusters with opposite characteristics would amplify its abnormality. Statistically, the $\mathrm{pH}$ value of category $\mathrm{HH}$ is not so much higher than category $\mathrm{O}$, while the concentrations of bicarbonate almost equal (Figure 5). Therefore, Cluster 3 is suggested to be a joint result of natural enrichment of alkalinity and spatial relationships. Given the above, the results of the CA stress the power of the MVA method for detecting singular behaviors of small groups of observations.

\section{Conclusions}

The present article reveals the complexity of spatial distribution of the soil salinity in the CBR basin, China. These soil chemical variables differ depending on the irrigation, groundwater table, terrain, irrigation regulation and the characteristics of the crops. The first two axes of PCA approximately explains $51 \%$ of the observed variability and allows distinguishing two main domains: the saline and the alkaline. In the RDA, the variability of the saline domain is obviously controlled by macro environmental factors, of which the density of canals and groundwater depth, respectively contributes $71 \%$ and $28 \%$. In contrast, the variability of the alkaline domain mainly manifests as singular behaviors of soil groups like rice-growing or sewage irrigation, which is detected by CA.

The last decades witnessed the transformation of the source of soil salt from groundwater to surface water. A double threat of them on soil salinization is coming in next few years due to the ongoing rise of groundwater table. Therefore, managers must find the right balance between their stand of groundwater and salinization of soil.

Sustainable agriculture in irrigated districts requires information about the salinity of the soils, incorporating many influence factors to achieve sound interpretations. The moderate percent of the variances explained in this study suggests that other unconsidered environmental and management factors should be considered in future research. Even so, MVA, specifically the complementary duo of RDA and CA, no doubt has enormous potential for integrating both global and local information to improve our understanding of linkages among soil salinity, environmental factors and management practices.

Author Contributions: Investigation and sampling, J.Z., D.D. and Y.B.; laboratory test, D.J.; statistical analysis, Z.J.; drawing, Z.J. and D.J.; writing—original draft preparation, Z.J.; writing—review \& editing, Z.J., D.J. and W.J. All authors have read and agreed to the published version of the manuscript.

Funding: This study was funded by the China Geological Survey (project DD20190251 and DD20190338).

Conflicts of Interest: The authors declare no conflicts of interest. 


\section{References}

1. Wang, X.L.; Guan, X.K.; Zhang, F.R.; Li, L. Agricultural utilization of saline-alkaline soil under the constraint of resources and environment in Tianjin. J. Nat. Res. 2016, 31, 1764-1772.

2. Lan, T.S.; Miao, J.J.; Bai, Y.N.; Ping, S.F.; Wang, F.G.; Cao, Y.Q. Hydrochemical characteristics and formation analysis of phreatic water in Tongzhou District of Beijing. Water Sav. Irrig. 2018, 12, 70-76. (In Chinese)

3. Wu, E.S.; Lin, E.Y.; Mu, H. Preliminary study on the relationship between several indicator plants and soil salinity in saline soil area of Hebei plain. J. Agric. Univ. Hebei 1982, 5, 122-131. (In Chinese)

4. Ma, H.Y.; Shen, Y.F.; Cao, Y. Characteristics of soil salinization in different area of Sino-Singapore Tianjin Eco-city. Geol. Survey Res. 2018, 41, 121-126. (In Chinese)

5. Li, J.G.; Chen, J.; Jin, J.X.; Wang, S.L.; Du, B. Effects of Irrigation Water Salinity on Maize (Zea may L.) Emergence, Growth, Yield, Quality, and Soil Salt. Water 2019, 11, 2095. [CrossRef]

6. Tian, K.X.; Li, H.Y.; Wang, R.; Wang, J.J. Water Conditions and Soil Salinization in Haihe Plain. 1999. Available online: http://119.78.100.206:8088/handle/311025/9209 (accessed on 1 May 2020). (In Chinese).

7. Wang, L.Y.; Guo, H.P. Efects of continuous drought on groundwater in Beijing plain. Hydrogeol. Eng. Geol. 2015, 42, 1-6. (In Chinese)

8. Zheng, J.K. Dynamic Response of Eco-Hydrological Process to Human Activities and Climate Change in Chaobai River Basin. Ph.D. Thesis, Beijing Forestry University, Beijing, China, 2011; pp. 17-20. (In Chinese).

9. Gong, H.L.; Pan, Y.; Zheng, L.Q.; Li, X.Y.; Zhu, L.; Zhou, C.F.; Zhang, C.; Huang, Z.Y.; Li, Z.P.; Wang, H.G. Long-term groundwater storage changes and land subsidence development in the North China Plain (1971-2015). Hydrogeol. J. 2018, 26, 1417-1427. [CrossRef]

10. Zhu, K.; Zhang, Y.X. South-to-North Water Diversion Project in China. Phys Rev. A 2008, 60, $982-985$.

11. He, Y.P.; Li, S.J.; Li, Y.; Meng, X.S.; Liu, C.J. Effect of South-to-North water transfer project on recharge and water level in Chaobai river area. Beijing Water 2019, 3, 21-26. (In Chinese)

12. Zhang, M.L.; Hu, L.T.; Yao, L.L.; Yin, W.J. Numerical studies on the influences of the South-to-North Water Transfer Project on groundwater level changes in the Beijing Plain, China. Hydrol. Process 2018, 32, 1858-1873. [CrossRef]

13. Johansson, M.; Stenberg, B. Multivariate techniques for presentation, interpretation and evaluation of soil quality data. In Soil Stresses, Quality and CareDIAS Report 38; Elmholt, S., Stenberg, B., Grønlund, A., Nuutinen, V., Eds.; DIAS: Tjele, Denmark, 2000.

14. Legendre, P.; Legendre, L.F. Numerical Ecology, 3rd ed.; Elsevier: Oxford, UK, 2012.

15. Aguilera, H.; Moreno, L.; Jiménez-Hernández, M.E.; Castaño, S.; la Losa, A.D. Management implications inferred from the multivariate analysis of vadose zone chemical variables in Las Tablas de Daimiel National Park (Spain). Geoderma 2011, 162, 365-377. [CrossRef]

16. Tug, G.N.; Ketenoglu, O.; Bilgin, A. The relationships between plant zonation and edaphic factors in halophytic vegetation around Lake Tuz, Central Anatolia, Turkey. Rend. Fis. Acc. Lincei 2012, 23, 355-363. [CrossRef]

17. Mora, J.L.; Herrero, J.; Weindorf, D.C. Multivariate analysis of soil salination-desalination in a semi-arid irrigated district of Spain. Geoderma 2017, 291, 1-10. [CrossRef]

18. Jiao, Y.M.; Zhao, N.; Yue, T.X.; Deng, J.Y. The effect of urbanization on extreme climate events in Beijing. Geogr. Res. 2020, 39, 461-472. (In Chinese)

19. Yu, Z.J.; Yang, P. Variation Characteristics of Pan Evaporation Capacity and Influencing Factors in Beijing-Tianjin-Hebei Region in Recent 40 Years. Meteorol. Sci. Technol. 2018, 46, 1180-1187. (In Chinese)

20. Soil Sub Center, National Earth System Science Data Center, National Science \& Technology Infrastructure. Available online: http://soil.geodata.cn (accessed on 1 May 2020).

21. Liu, H.L. Review of farming irrigation in Beijing. Trans. Chin. Soc. Agric. Eng. 1998, 1, 70-75. (In Chinese)

22. Cai, S.Y.; Li, Q.; Zhao, X.G.; Xia, Z.L.; Mu, C.R.; Li, S.Z. Study on the impact of sewage irrigation on ecological environment in Beijing, Tianjin and Tangshan area and the countermeasures. J. Ecol. Rural Environ. 1985, 1, 1-5. (In Chinese)

23. Yu, M.; Wei, Y.S.; Zheng, X.; Wang, Y.W.; Zhong, J.; Yang, Y.; Xiao, Q.C.; Yu, D.W. Evolution of hydro-chemical characteristics of Wenyu River and its influencing factors. Acta Sci. Circumst. 2012, 1, 1-8. (In Chinese)

24. Liu, Y.; Meng, D.; Zhou, Y.B. Contribution factors to grain production increase based on gravity center model and lmdi model in Beijing-Tianjin-Hebei region from 1990 to 2010. Econ. Geogr. 2014, 34, 125-130. (In Chinese) 
25. Aumond, P.; Can, A.; Mallet, V.; Coensel, B.D. Kriging-based spatial interpolation from measurements for sound level mapping in urban areas. J. Acoust. Soc. Am. 2018, 143, 2847-2857. [CrossRef]

26. Gaparovi, M.; Rumora, L.; Miler, M.; Medak, D. Effect of fusing Sentinel-2 and WorldView-4 imagery on the various vegetation indices. J. Appl. Remote Sens. 2019, 13, 1. [CrossRef]

27. Hill, M.O.; Gauch, H.G. Detrended correspondence analysis: An improved ordination technique. Vegetatio 1980, 42, 47-58. [CrossRef]

28. Alger, K.; Bunting, E.; Schuler, K.; Whipps, C.M. Risk factors for and spatial distribution of Lymphoproliferative Disease Virus (Lpdv) in Wild Turkeys (Meleagris Gallopavo) in New York State, USA. J. Wildl Dis. 2017, 53, 499-508. [CrossRef] [PubMed]

29. Cao, G.X.; Wang, K.Q.; Zhao, Y.Y.; Duan, X. The mechanism of surface runoff and sediment yield of evergreen broad-leaved forest in the middle subtropical region. J. Soil Water Conserv. 2018, 32, 30-36. (In Chinese)

30. Bradley, B.; Schweik, C.M. Introduction to geographic science using ArcGIS V10. Clin. Chem. 2012, 20, 1131-1134.

31. Lu, R.K. Analysis Method of Agricultural Chemistry in Soil; Agricultural Science and Technology Press: Beijing, China, 2000. (In Chinese)

32. Visconti, F.; José, M.D.P.; José, L.R. Principal component analysis of chemical properties of soil saturation extracts from an irrigated Mediterranean area: Implications for calcite equilibrium in soil solutions. Geoderma 2009, 151, 1-416. [CrossRef]

33. Cui, G.Q.; Lu, Y.D.; Zheng, C.; Liu, Z.H.; Sai, J.M. Relationship between Soil Salinization and Groundwater Hydration in Yaoba Oasis, Northwest China. Water 2019, 11, 175. [CrossRef]

34. Zhang, C.W.; Zhu, Q.; Liu, C.Y.; Zuo, L.M. Analysis of groundwater and soil salinity in delta region of Luanhe River estuary. Yangtze River 2017, 48, 17-20. (In Chinese)

35. Wang, J.Y.; Liu, Y.X.; Wang, S.M.; Liu, H.M.; Fu, G.Q.; Xiong, Y.C.; Aitkenhead, M. Spatial distribution of soil salinity and potential implications for soil management in the Manas River watershed, China. Soil Use Manage 2019, 36, 93-103. [CrossRef]

36. Herrero, J.; Pérez-Coveta, O. Soil salinity changes over 24 years in a Mediterranean irrigated district. Geoderma 2005, 125, 287-308. [CrossRef]

37. Yu, R.P.; Yang, D.P. Studies on the process of soil alkalization I. The effect of sodium bicarbonate on the alkalization of soil. Acta Pedol. Sin. 1982, 19, 344-350. (In Chinese)

38. Yang, C.; Li, J.J.; Zhang, Y.J. Soil aggregates indirectly influence litter carbon storage and release through soil $\mathrm{pH}$ in the highly alkaline soils of north China. PeerJ 2019, 7, e7949. [CrossRef] [PubMed]

39. Mack, U.D.; Feger, K.H.; Gong, Y.S.; Stahr, K. Soil water balance and nitrate leaching in winter wheat-summer maize double-cropping systems with different irrigation and $\mathrm{N}$ fertilization in the North China Plain. J. Plant Nutr. Soil Sci. 2005, 168, 454-460. [CrossRef]

40. He, G.; Wang, Z.H.; Li, F.C.; Dai, J.; Ma, X.L.; Li, Q.; Xue, C.; Cao, H.B.; Wang, S.; Liu, H.; et al. Soil nitrate-N residue, loss and accumulation affected by soil surface management and precipitation in a winter wheat-summer fallow system on dryland. Nutr. Cycl. Agroecosyst. 2016, 106, 31-46. [CrossRef]

41. Zhang, C.S.; Fay, D.; McGrath, D.; Grennan, E.; Carton, O.T. Statistical analyses of geochemical variables in soils of Ireland. Geoderma 2008, 146, 378-390. [CrossRef]

42. Momtaz, H.R.; Jafarzadeh, A.A.; Torabi, H.; Oustan, S.; Samadi, A.; Davatgar, N.; Gilkes, R.J. An assessment of the variation in soil properties within and between landform in the Amol region, Iran. Geoderma 2009, 149, 10-18. [CrossRef]

43. Tiemeyer, B.; Frings, J.; Kahle, P.; Köhne, S.; Lennartz, B. A comprehensive study of nutrient losses, soil properties and groundwater concentrations in a degraded peatland used as an intensive meadow-Implications for re-wetting. J. Hydrol. 2007, 345, 80-101. [CrossRef]

44. Wang, Y.Q.; Zhang, X.C.; Zhang, J.L.; Li, S.J. Spatial variability of soil organic carbon in a watershed on the Loess Plateau. Pedosphere 2009, 19, 486-495. [CrossRef]

45. Fan, L.Q.; Li, L.; Wu, X. Relationship between soil salinity and groundwater characteristics in saline-alkali land with high groundwater level of Yinbei Irrigation area. Water Saving Irrig. 2019, 6, 55-59. (In Chinese)

46. Jiang, M.L.; Chen, X.B.; Shan, J.J.; Guo, J.Q.; Sun, Y.P.; Zhao, L.Y.; Xu, L.G. On chemical parameters characteristics of salinity soil on county scale in Yellow River Delta. Soils 2017, 49, 992-1000. (In Chinese)

47. Stanley, D.M.; Wilkin, R.T. Solution equilibria of uranyl minerals: Role of the common groundwater ions calcium and carbonate. J. Hazard. Mater. 2019, 377, 315-320. [CrossRef] [PubMed] 
48. Leps, J.; Smilauer, P. Multivariate Analysis of Ecological Data Using CANOCO; Cambridge University Press: Cambridge, MA, USA, 2003.

49. Jiang, T.S.; Sun, Y.W.; Yang, Z.S.; Zhang, R.L.; Huang, Z.F.; Wang, Y.M. Analysis of the Surface Water Chemical Characteristics Variance in the Beiyunhe River Basin. J. Irrig. Drain. 2012, 31, 82-86. (In Chinese)

50. Wang, Y.X.; Feng, Z.L.; Qiu, Q.T.; Zhang, S.; Lin, H.X.; Wang, G. An Analysis of the Influence of Chemical Composition of Groundwater in the Liangji Canal Basin on South-to-North Water Transfer Project in Operation. China Rural Water Hydropower 2015, 11, 110-114. (In Chinese)

51. Kevin, M.H.; Victor, F.B. Hydrogeology: Principles and Practice, 2nd ed.; Blackwell Pub: Boboken, NJ, USA, 2007; pp. 37-38.

52. Badía, D.; Martí, C.; Poch, R.M. A soil toposequence characterization in the irrigable lands-Protected area contact zone of El Basal, NE-Spain. Arid Land Res. Manag. 2011, 25, 1-18. [CrossRef]

53. Herrero, J.; Netthisinghe, A.; Hudnall, W.H.; Pérez-Covetaa, O. Electromagnetic induction as a basis for soil salinity monitoring within a Mediterranean irrigation district. J. Hydrol. 2011, 405, 427-438. [CrossRef]

54. Abliz, A.; Tiyip, T.; Ghulam, A.; Halik, U.; Ding, J.L.; Sawut, M.; Zhang, F.; Nurmemet, L.; Abliz, A. Effects of shallow groundwater table and salinity on soil salt dynamics in the Keriya Oasis, Northwestern China. Environ. Earth Sci. 2016, 75, 260. [CrossRef]

55. Li, M.; Ning, L.B.; Lu, T.M. Determination and the control of critical groundwater table in soil salinization area. J. Irrig. Draina. 2015, 34, 46-50. (In Chinese)

56. Xie, T.; Liu, X.H.; Sun, T. The effects of groundwater table and flood irrigation strategies on soil water and salt dynamics and reed water use in the Yellow River Delta, China. Ecol. Model. 2011, 222, 241-252. [CrossRef]

57. Yang, Y.D.; Li, X.H.; Wang, L.H.; Li, C.Q.; Liu, Z.H. Characteristics of the groundwater level regime and effect factors in the plain region of Tianjin city. Geol. Surv. Res. 2011, 34, 313-320. (In Chinese)

58. Xiang, J.; Haden, V.R.; Peng, S.B.; Bouman, B.A.M.; Vispera, R.M.; Nie, L.X.; Huang, J.L.; Cui, K.H. Improvement in nitrogen availability, nitrogen uptake and growth of aerobic rice following soil acidification. Soil Sci. Plant. Nutr. 2009, 55, 705-714. [CrossRef]

59. Shen, J.N.; Wang, H.Y.; Lu, J.J.; Hu, S.S.; Hu, X.Y.; Guan, Y.J.; Wu, H.B.; Miao, D.Y.; Wang, H.Z.; Tang, Q.G.; et al. Study on regulating $\mathrm{pH}$ status in seedbed of cold rice. North. Rice 2015, 45, 10-13. (In Chinese)

60. Chen, Y.Q.; Zhang, G.X.; Xu, Y.; Huang, Z.G. Influence of Irrigation Water Discharge Frequency on Soil Salt Removal and Rice Yield in a Semi-Arid and Saline-Sodic Area. Water 2013, 5, 578-592. [CrossRef] 